\title{
NEDERLAND EN DUITSCHLAND AAN DE EEMS.
}

\author{
II.
}

\section{De haven van Delfzijl.}

Delfzijl heeft nimmer, gelijk Emden, historische beteekenis gehad. In de laatste helft der zestiende eeuw was het nog een onder Opwierde behoorend dorp. De naam duidt den oorsprong aan: Zijl (of siel) van de Delf, een gegraven (gedolven) waterloop, misschien de rivier de Fivel, die bij den aanleg der sluizen uitgegraven werd, misschien een kunst matige afwatering. In eene orkonde van 1303 is sprake van het Zijlvest (waterschap) de drie Delfzilen. Dat waterschap loosde ziju water door drie sluizen op de Eems, de Dorpster-, Scharmer- en Slochter zijlen. Bepalingen voor het zijlvest vindt men iu eene oorkonde van 1317, waarin o. a. Delfsilum als plaats van samenkomst voor de scheppers van het zijlvest, dat later in het groote waterschap Fivelingo is opgenomen, wordt aangewezen. In de kronieken van Fmo en Menco, geschreven in 1237, wordt het jaar 1192 genoemd als dat, waarin de sluizen zouden zijn gelegd. ") Tegenwoordig wordt het water van Fivelingo geloosd in de haven van Delfzijl door de sluizen, die het Damsterdiep, in 1650 gekanaliseerd, van het buitenwater afscheiden. Vlak daarnaast ten Zuiden treft men sedert 1874 , de groote uitwateringsen schutsluis van het Eems- of Groot-scheepvaarlkanaal aan, waardoor al het water uit de Groningsche en Drentsche veenstreken, dat $\nabla 66 r$ dien tijd langs de open rivier, het Reitdiep, op zeer gebrekkige wijze naar de Noordzee afstroomde, mede op de Eems wordt geloosd. Nog iets Zuidelijker ontvangt de haven door de uitwateringssluis van Duurswold het water van dat belangrijke waterschap. ${ }^{2}$ ) Voor de waterloozing van een

1) Deze bijzonderheden vond ik vermeld in eenige artikelen over de geschiedenis van Delfzijl van T. de Vries in de Volkscourant te Appingedam van 22 Juli 1897 e. v.

$\left.{ }^{2}\right)$ Vgl. Beekman «Nederland als polderland», Zutphen 1884, pag. 374-5. 
groot deel der Provinciën Groningen en Drenthe is de haven van Delfzijl dus van groote beteekenis. Hare beteekenis voor de scheepvaart dagteekent van de openstelling van het Eemsof Groot-scheepvaartkanaal. Vroeger deed zij hoofdzakelijk dienst als nood- of vluchthaven. Den $6^{\mathrm{e}}$ Augustus 1665 , korten tijd na het uitbreken van de tweede Engelsche oorlog, kwam van Delfaijl de blijde boodschap, dat de Ruiter met zijn eskader, de door hem geleide West-Indische handelsvloot en prijsgemaakte Engelsche koopvaarders de Engelschen, die op hem loerden, om de Schotsche kust ontzeild en behouden daar binnen gekomen was. $\mathrm{Na}$ de openstelling van het Eemskanaal en de afsluiting van het Reitdiep door de sluis te Zoutkamp, kwam het oude zeegat van de stad Groningen voor zeeschepen in onbruik. Deze kwamen voortaan te Delfzijl binnen en vonden van daar naar Groningen een recht en breed kanaal in de plaats van de bochtige rivier, langs welke de vloed ze vroeger naar de stedelijke haven droeg. Aan de verwachtingen zijner ontwerpers heeft dat "G root"-scheepvaartkanaal evenwel niet beantwoord. Voor groote scheepvaart is het ongeschikt. Zijn diepgang nominaal 4.5 M. onder W. P., meestal niet meer dan 4. $M$. inderdaad, is daarvoor onvoldoende en het aantal en de wijze van constructie der vele bruggen belemmeren de vaart. Toch heeft Delfzijl door dat kanaal aan beteekenis gewonnen, vooral voor den houthandel.

Aan plannen om de nabijheid van een grooten en diepen riviermond aan de scheepraart en den handel van Groningen dienstbaar te maken, heeft het in den loop der tijden niet ontbroken. Zoo werd in 14.83 eene overeenkomst gesloten tusschen den Bisschop van Munster en de stad Groningen, om een kanaal te graven uit de Bems bij Heede door de Bourtanger veenen naar de stad Groningen "20 voet wijd in den bodem en zoo diep, dat de Eems zijn loop daardoor nemen zoude " ${ }^{1}$ ). Aan de uitvoering van dat, voor dien tijd stoute plan, is van Duitsche zijde de hand geslagen; de sporen er van moeten nog te vinden zijn, maar de technische moeilijkheden bleken

1) Zie «Bijdrage tot de Geschiedenis en Oudheidkunde inzonderheid van de Provincie Groningen van Dr. G. Acker Stratingh, Mr. H. O. Feith en Mr. W. B. S. Boeles, $3^{e}$ deel, pag. 133, uitg: Groningen 1866. 
in dien tijd onoverkomelijk. In de $17^{e}$ en in het begin der $18^{\mathrm{e}}$ eeuw is het plan nog weder ter sprake gebracht, maar tot uitroering is het nimmer gekomen. De bedoeling, die de contractanten hadden, was, om aan den tol, door Emden geheven en het stapelrecht door die plaats uitgeoefend, te ontkomen. Datzelfde stapelrecht, ook door de stad Groningen met groote gestrengheid gehandhaafd, gaf in de $15^{\mathrm{e}}$ en $16^{\mathrm{e}}$ eeuw aanleiding tot veelvuldig getwist tusschen beide plaatsen. Verdragen werden naar aanleidiug daarvan gesloten, en, gelijk meer voorkomt, verbroken. Zoo sloot de stad Groningen met den Graaf van Oost-Friesland, Ulrich van Cirksena in 1457 een verdrag tot vaststelling van wederzijdsche rechten en tot verleening van wederzijdsche voorrechten, inaar onder de regeering van Keizer Karel $V$ was men weder hevig aan het twisten, ook al naar aanleiding van het bovenvermelde door Groningen met den Bisschop van Munster gesloten verdrag, waarbij de Keizer te pas kwam, die het zeer door ketterij besmette Emden in 't ongelijk stelde.

De Hertog van Alva had groote planien met Delfzijl. Hij wilde er een groote stad en haven stichten. die Marsburg zoude heeten, den Eemsmond zoude beheerschen en voor Emden eene krachtige mededinging in 't leven roepen. Maar ditmaal protesteerde de stads-regeering van Groningen, bevreesd voor die nieuwe mededingster, en de hertog, minder vasthoudend dan waar het zijne belastingplannen gold, gaf het plan op en bepaalde zich tot het bouwen van een fort ${ }^{1}$ ).

Indien Delfzijl, evenals Emden eene Pruisische stad was geweest, toen de Pruissische regeering besloot tot het maken van een groote haven aan den mond van de Eems en die regeering daarvoor tusschen Emden en Delfzijl had moeten kiezen, zonder twijfel ware de keus op Delfzijl gevallen. De natuurlijke voordeelen van deze plaats zouden de keus ontwijfelbaar in haar voordeel bepaald hebben. Ten eerste ligt zij 10 kilometer dichter bij zee dan Emden, onmiddellijk aan den mond van de rivier, van welke rivier Emden bijna 3 kilometers

1) Zie sTegenwoordige staat van stad en landex, dl. I, bl. 12 en dl. II, bl. 364-5 en: «Over de Eems als handel en grensstroom», zie de «bijdragen» van Dr. Acker Stratingh c. s., dl. II, pag. 202 e. $\nabla$. 
verwijderd is. Voorts treft men onmiddelijk buiten de haven van Delfzijl bij eb $8 \mathrm{M}$, , bij vloed pl. m. $10.30 \mathrm{M}$. diepgang. De weg naar zee van Emden daarentegen moest gemaakt worden ten koste van vele millioenen. En bovenal, Delfzijl is wel niet volkomen ijsvrï, maar het gevaar voor sluiting van zijne haven in den winter is veel geringer dan voor de andere, zoodat dan ook de "Ems-Loots-Gesellschaft" in den winter hare loods-schooners te Delfzijl stationeert, ten einde te voorkomen, dat ze in Emden invriezen ${ }^{1}$ ). Delfzijl had evengoed als Emden de zeehaven van het Dortmund-Eems kanaal kunnen zijn en staat aan de landzijde door flinke kanalen met belangrijke handels- en industrieplaatsen in verbinding Maar, nu de Duitsche haven tot stand gekomen is, ligt daarin voor ons bestuur geen reden om de voordeelen, die de ligging van Delfzijl aanbiedt, ongebruikt te laten. Vooral niet, omdat de behoorlijke inrichting van een flinke haven daar ter plaatse geen uitgaaf van $f 50$ millioen zal vorderen, maar voor een tiende deel van die som reeds heel wat schijnt te kunnen worden bereikt. Jaat men niet zeggen, dat ons kleine land aan twee groote havenplaatsen, Rotterdam en Amsterdam genoeg heeft, noch dat men het werk moet nalaten uit vrees, dat aan het verkeer van deze beide afbreuk zal worden gedaan ${ }^{2}$ ). Hoe weinig die vrees behoeft te weerhouden; leert het voorbeeld van Amsterdam en Rotterdam. De ingenieurs Van Hasselt eu de Koning wijzen er in hun ontwerp voor de verbetering vau de haven te Delfzijl op, dat de tonnemaat der in 1899 door de Noordzee-sluizen te IJmuiden geschutte schepen $3 \frac{1}{2}$ Inaal zoo groot was als in 1878 , niettegenstaande Rotterdam in die jaren op een reusachtige uitbreiding kan wijzen, zoodat van 1880 tot 1897 de hoeveelheid der aldaar aangekomen goederen naar het gewicht met 275 pCt. is vermeerderd ${ }^{3}$ ). Een groote haven in het Noordwesten van ons land zal haar eigen verkeer verkrijgen en een kostbaar bezit blijken te zijn. Verzuimden wij

1) Zie ontwerp voor de verbetering van de haven te Delfzijl, Van Hasselt en de Koning, Nijmegen bij G. J. Thieme, pag. 11.

2) De haven van Harlingen gebracht op 5.5 M. beneden volzee is voor de grootste stoombooten te ondiep.

3) In Antwerpen bedroeg in denzelfden tijd de vermeerdering $87 \mathrm{pCt}$, in Hamburg $223 \mathrm{pCt}$.

ECON. 1902. 
ons dat bezit te verwerven, wij: zouden handelen als de landbouwer, die goede gronden, wet weinig kosteu te ontginnen, uit gebrek aan ondernemingslust onontgounen laat. De provinciën Groningen en Friesland en ook het eertijds arme Drenthe, dat door de zuinigheid en arbeidzaamheid zijner bewoners en door ... kunstmest zeer in welvaart toeneemt, zullen het achterland van onze Eemshaven aiju, het achterland, dat de haven tot bloei brengt en dat op zijne beurt in zijne ontwikkeling door de nabij gelegen haven krachtig zal worden gesteund. De Heeren van Hasselt en de Koning treden in hun "ontwerp" teu aanzien van dit punt in nadere bijzonderheden eu becijferingen, die ik niet wel kan overnemen, maar die het overwegen zeer waard zijn. De Noordooster locaal spoorweg zal binnen eenige jaren Delfaijl in directe verbinding brengen met de belangrijke nijverheid in de Groningsche veenkoloniën, met de Drentsche veenderijen en met de Twentsche fabriekeu. Met aardappelmeel en stroo-carton, meț turfstrooisel, misschien ook met gebakken steen, zullen de stoombooten, die graan en hout en steenkolen, wellicht straks ook ijzer aanbrengen, kunnen worden beladen. Voor allerlei industrie, de ervaring beeft het geleerd, bieden deze streken, doonsneden als zij zijn door talrijke kanalen, ruime gelegenheid. De aardappelmeelfabrieken leverden in 1899 circa 665.000 balen meel,

in $1900 " 365.000 "$ "

in 1901 " $485.000 "$ " (hiervan werden cirea 30.000 over Delfzijl, het overige langs andere wegen nitgevoerd).

De fabrieken van stroocarton in deze provincie hebben in de twee jaren 1900 en 1901 te samen afgeleverd ongeveer 185.000 ton a 1000 KG.: en de fabriek te Leeuwanden ongeveer 33.000 ton.

Is eenmaal de groote haven nabij, dan zal, dark zij goedkoop vervoer naar het zeeschip, die industrie tot krachtiger ontwikkeling kunnen komen.

In Duitschland wordt de groote belangrijkheid van Delfzij] zeer goed ingezien. Vón Palmgrên zegt er van: ")

"Met het oog op de groote veranderingen, die Emden en "de andere Eemshavens tegemoet gaan, mag de nabijheid van.

1) Pag. 125. 
"Nederland, in 't bizonder van de haven van Delfzijl niet "ẉorden vergeten. In de laalste jaren is uit deze plaats alles min het werk gesteld, om ook een aandeel in het verkeer op "den nieuwen waterweg, het Dordmund-Eemskanaal, te verkrijgeu. "en het transito-verkeer tot zich te trekken. Na den overgang "van de haven aan den Staat zijn zoowel de havengelden af"geschaft, als ook aan het transito verkeer belangrijke tege"moetkomingen geschonken. De inrichting van de haven van "Delfzijl maakte in den afgeloopen winter $(1900 / 1)$ een onder"Werp van bespreking in de Nederlandsehe Kamers uit. Men "verschilde in zooverre van meening, dat eenige afgevaardigden "voor versnippering van krachten waarschuwden en den raad "gaven alle krachten aan Amsterdam en Rotterdam te wijden, "terwijl anderen - en ook de Minister van Waterstaat, Handel "en Nijverheid - voor de uitbreiding van Delfzijl's haven "spraken. In verband daarmede hebben Nederlandsche Inge"ulieurs, evenals vertegenwoordigers van handiel en scheepvaart, "de haven- en kanaal-toestanden aan de Beneden-Eems in noogenschouw genomen, teu einde te bepalen, welke maat"regelen getroffen kunnen worden om aan de haven van "Delfaijl, evenals aan de hoofdstad der provincie Groningen nover het Dortmund-Eems kanaal een grooter verkeer met "West-Duitschland te bezorgen. De Groningsche kamer van "Koophandel verlangt verbreediug van het kanaal Groningen"Delfzijl, zoodat zeeschepen tot Groningen kunnen opkomex; "buitendien verlangt zij een zoodanige verbetering ran de "haven te Delfzijl, dat deze plaats zich met goed gevolg zal "kunnen meten met de Pruissische Eemshavens. Wanneer ook „al Delfzijl tengevolge van zijne ligging zekere voordeelen met. "betrekking tot het verkeer ter zee anbiedt, zoo kan Émden "toch op een belangrijken voorsprong in het handelsverkeer "bogen, op grond van zijne geschiedenis en van zijne ligging mals uitgangspunt van den nieuwen waterweg. Desniettegen"staande, en ofschoon onze betrekkingen met den Westelijken "buurman zoo goed mogelijk zijn, heeft toch tusschen Emden "en dien buurman altijd eenige wedijver bestaan. Immers be"schouwden de Nederlanders gedurende langen tijd de Eems "als hun uitsluitend bezit en beproefden den zeehandel van. "Emden in elk opzicht te benadeelen. Zijn de tijden ook al 
"zeer veranderd, toch zullen Emden en de andere Eemshavens "de hollandsche mededinging niei uit het oog moeten verliezen."

De schrijver wijst dan op de groote voordeelen, die de wet van 22 Juli 1899 door afschaffing van alle tollen op wegen, kanalen, bruggen, sluizen enz. aan het verkeer te water heeft geschonken en pleit op dien grond voor groote vrijgevigheid ten aanzien van loods-, haven- en kanaalgelden ten behoeve van het transito-verkeer. Het is hem blijkbaar niet bekend, dat geuoemde wet alleen de rijkskaualen en wegen betreft en dat de kanalen, die van Delfzij] naar Groningen en verder naar de Zuiderzee leiden, provinciale kanalen zijn, nog steeds met niet geringe lasten bezwaard.

Iets verder wijst de schrijver erop, dat in de memorie van toelichting tot de begrootingpost, anwijzend de middelen om de Emder havenwerken te voltooijen, door de Pruissische regeering betoogd wordt, dat inrichting van een vrijhaven gebied, gelijk Hamburg, Bremen en andere havens bezitten, voor Emden eene noodzakelijkheid is, "de bereiking van het nationale doel, "de Duitsche haven Emden in de plaats der Nederlandsche "en Belgische havens Rotterdam, Amsterdam en Antwerpen tot "in- en uitroerhaven voor een deel van het belangrijkste "Pruissische iudustrie-gebied te maken, hangt.... zeer stellig "daarvan af, dat in Emden een vrijhaven gebied wordt ingericht; ;" en later: "Bleef Emden van deze, voor de ontwikkeling van "de geheele groote en kostbare onderneming noodzakelijke inrich"ting verstoken, dan zoude zich de naburige Nederlandsche haven "Delfzijl tot vrijhaven voor de Wems en voor het Dortmund-Eems "kanaal ontwikkelen, voor zoover het verkeer van Rotterdam, "Amsterdam en Antwerpen zoude kunnen worden afgeleid.".

Uit deze aanhalingen blijkt, hoezeer men in Duitschland in regeerings-kringen en elders, van het helang van Delfzijl als mogelijke mededingende haven van Emden overtuigd is. Zien wij nu weike plannen ten opzichte van Delfzijl bij onze regeering bestaan en hoever men met de nitvoering daarvan gevorderd is.

Uit het verslag van den toestand der Provincie Groningen over het jaar 1899 hlijkt, dat de uitbreiding aan de Emder haven. gegeven, in verband met de openstelling van het Dortmund- 
Eems kanaal en met den eerlang te wachten aanleg van den Noord-ooster-Locaalspoorweg, met Delfzijl als eind-station, den Gemeenteraad van Delfzijl, de Kamer van Koophandel en Fabrieken aldaar, en de ingezetenen dier plaats de oogen geopend heeft voor de noodzakelijkheid om de haven dier plaats beter in te richten dan tot nu toe. Ik wil niet beweren, dat men vóór dien tijd voor dat belang geen oog heeft gehad, integendeel ook vroeger zijn wel plannen ontworpen en is de aandacht der Regeering op de belangen van Delfzijl gevestigd, maar men heeft begrepen, dat nu de tijd roor krachtig handelen gekomen was, begrepen ook, dat hier een algemeen Nederlandsch belang met het plaatselijk belang samenvalt. Ditmaal heeft de belangstelling voor deze zaak zich in wijderen kring geuit. Adressen van de genoemde lichamen en van een groot aantal ingezetenen vau Delfzijl, hebben bij de Tweede Kamer der Staten-Generaal de belangen van hunne haven bepleit. De Kaner van Koophandel en Fabrieken te Groningen heeft, op verzoek van haren Voorzitter, hare aandacht gewijd aan de vraag, "of de openstelling van het Dordmund-Eemskanaal "ook haren invloed zal doen gevoelen op handel en scheepvaart "van ons land, ineer speciaal van de streek onder het ressort "der Kamer vallend; of het, in verband daarmede, niet aaube"veling verdient, de doeltreffendheid der haven te Delfzijl en "bijbehoorende iurichtingen te onderzoeken en vervolgens de „vraag te stellen, of die haven en hare inrichtingen in staat "zijn, in ernstige concurrentie met die van Emden te treden; "eindelijk welk belang Groningen heeft bij den bedoelden "nieuwen waterweg." De overweging van die vrag heeft de Kamer, op voorstel eener commissie van advies, doen besluiten, het initiatief te nemen tot het stiohten eener vereeniging, die zich tem doel stelt de noodige maatregelen te nemen, ten einde eene radicale verbetering van deu waterweg van Groningen naar de Eems voor te bereiden ').

In eene vergadering van verschillende vertegenwoordigers van handel en scheepraart werd den 10 Februari 1899 een besluit genomen als door de Kamer vay Koophandel voorge-

1) Het rapport, waarvan dit advies de conclusie vormt, is in zijn geheel opgenomen in het verslag van den toestand der Provincie voor 1899 op pag. 213 e. . 
steld en de gewenschte vereeniging daarna opgericht, evenwe. met een ruimer programma dan door de adviseurs der Kamer van Koophandel bedoeld. De vereeniging zoude bevorderen de verbetering, zoowel van de haven van Delfzijl als van de waterwegen naar Groningen, in het bijzonder van bet Eemskanaal en van het kanaal Groningen-de Lemmer. Dat in de omsehrijving van het doel der vereeniging de haven van Delfzijl op den voorgrond is gekomen en verbetering van het Eemskanaal in de tweede plaats wordt genoemd, is geene toevalligheid, maar gevolg van de overweging, dat de vereeniging in de eerste plaats behoort te streven naar het meest noodige en naar het in den eersten tijd bereikbare. Het Lems-kanaal voor diepgaande stoombooten geschikt te maken, is een werk van zoudanigen ouvang en zoude een zoo groote uitgaaf vorderen, dat daaraan in den eersten tijd wel niet te denken zal zijn. Dat ook de zeer noodige verbetering van de vaart Groningen-de Lemmer in het pogramma der vereeniging is opgenomen, is een gevolg van de samensmelting eener reeds bestaande en voor dat doel werkzame vereeniging met de nieuw opgerichte.

Op welke wijze het bestuur der vereeniging is begonnen uitvoering te geven aan het ontvangen mandaat, blijkt uit het jaarverslag, uitgebracht in de algemeene vergadering van 28 December 1901. Daaruit zien wij, dat het bestuur aan de ingenieurs J. van Hasselt en de Koning te Nijmegen heeft opgedragen, ter uitvoering van art. 2 van de Statuten der vereeniging luidend: "een volledig en grondig onderzoek (zoo "technisch als financieel) in te stellen, naar de wijze waarop "het doel, waarmede de vereeniging is opgericht, het best "kan worden bereikt" en, nadat op advies van die heeren besloten was de planuen betreffend het Eemskauaal voorloopig te laten rusten, outwerpen te maken voor de verbetering van de haven van Delfaijl en voor de vaart Groningen-de Lemmer. Alleen het eerste dier ontwerpen is voor 't oogenblik voor ons van belang. Daarvoor moest rekening worden gehouden met de plannen der Regeering, die toen reeds een begin van uitroering hadden verkregen. De rraag: binnen- of buitenhaven, werd door het bestuur, gehoord zijne deskundigen, in laatstgenoemdeu zin heslist, en den $31^{\text {en }}$ Maart 1901 werd hun nader opgedragen daarvoor een outwerp te maken. Reeds den $23 \mathrm{Mei}$ 
d. a. v. kon een, ingevolge den hun opgedragen last, door de genoemde ingenieurs vervaardigd voorloopig plan met begrooting van kosten worden behandeld. Besloten werd dit ontwerp te doen drukken en aan de leden der vereeniging te zenden.

Alrorens verder dit outwerp te bespreken, is het noodig na te gaan, wat door de regeering en de wetgevende macht voor Delfzijl intusschen was gedaan en voorbereid.

Hetgeen bij de behandeling der begrootingen van Waterstaat, Handel en Nijverheid voor 1900 en 1901 in de afdeelingen en bij de openbare behandeling door den Minister en door leden der Eerste en Tweede Kamer der Staten-Generaal over Delfzijl is gezegd, vindt men, behalve in de "Handelingen" uitvoerig vermeld in de verslagen over den toestand der Proviucie Groningen voor 1899 en 1900.

$\mathrm{Op}$ het negende hoofstuk der begrooting voor 1900 werd eene post van $\mathrm{f} 66.500$ angetroffen, ten behoeve van de haven van Delfzijl. Volgens de toelichting door den Minister gegeven was vau die post eene som van $\mathrm{f} 25.800$ bestemd voor baggerwerk in de haven en $f 30.000$ voor eersten termijn van een nieuw werk, het maken eener basaltkade aan die haven voor diepgaande schepen met spoorwegverbinding. De Minister raamde toen dat werk op $\mathrm{f} 300.000$. Van twee zijden stond zijn beleid aan kritiek van de Kamerleden bloot. Eenerzijds van de zijde van hen, die waarschuwden tegen het streven, om Delfzijl tot een groote haven te maken en de concurrentie met Emden op te nemen. De kosten, daarvoor besteed, waren nuttiger aangewend voor onze groote havens. Blijkens het voorloopig verslag was zelfs bij de behandeling der begrooting in de afdeelingen door eenige leden bezwaar gemaakt tegen de jaarlijksche aanzienlijke (sic) uitgaven voor deze haven ${ }^{1}$ ) Die leden achtten blijkbaar elken gulden voor Delfzijl uitgegeven, weggeworpen en schenen de meening toegedaau, dat men Delfzijl maar aan zijn lot moest overlaten. Het was de heer van Karnebeek, die de planneu, welke de Minister met Delfzijl had, bestreed, o. a. door te wijzen op de ervaring net Vlissingen opgedaan, waar de poging om een deel van de handelsbeweging van Antwerpen naar die haven te trekkeu, niets dan teleurstelling had gebaard.

1) Op 1 Juli 1897 is de haven van Delfzijl door het Rijk in onderhoud overgenomen. 
Achter Emden, zoo meende hij, stond de gansche kracht van het Duitsche rijk, dat elke concurrentie onmogelijk zoude maken. Danrentegen kwam van den lieer Zijlma een krachtige aansporing tot meer voortvarendheid in de uitvoering der plannen. Deze spreker wees op de natuurlijke voordeelen van Delfzijl boven Emden en wilde eene commissie tot onderzoek en tot het ontwerpen van een plan en de heer Pijttersen viel hem bij. Eene commissie, antwoordde de Minister, zal geene bespoediging, wel vertraging geven; een eerste gevolg van hare benoeming zoude zijn, dat de voorbereiding van een plan, aan 's Ministers departement in bewerking, voorloopig gestaakt zoude worden. De Minister deelde tevens aan de kamer mede, wat hij wet Delfzijl voorhad en bestreed daarbij de meening van deu Heer van Karnebeek. De zeevaart, zoo betoogde hij, ontwikkelt zich, waar zij de kansen gunstig vindt. Op eene reis, door hem gemaakt naar Emden en Delfzijl, had hij de overtuiging gekregen, dat het, zoowel wegens den aanleg der Noordooster-locaal spoorweg, als met het oog op de mogelijkheid, dat, tengevolge van den aanleg der haven van Emden, de scheepvaart op de Eems zich zoude ontwikkelen, wenschelijk is de haven van Delfzijl niet alleen te verbeteren, maar geschikt te maken tot het laden en lossen van betrekkelijk groote schepen. Maar de Minister wilde daarbij gelijdelijk te werk gaan, eerst tot stand brengen, hetgeen onmiddelijk noodig is en dat wel op zoodanige wijze, dat, als het verkeer zich blijkt te ontwikkelen, een groote uitbreiding in de toekoust aan de voorloopig beraamde werken kan worden aangepast. Thans, zoo zeide de Minister, kan de haven voor het lossen van deu spoorweg in groote schepen en ongekeerd niet gebruikt worden, omdat er geene kade is, warr zulke schepen kunnen liggen. Het verkeer in de haven bepaalt zich tot houtschepen, die hunne lading in de haven overboord werpen, en tot schepen, die er binnenvallen om langs het Eemskanaal naar Groningen op te varen. Er bestaat dus behoefte aan eene kade, aan welke een paar groote schepen naast elkander kunnen liggen. Het opmaken van het ontwerp voor zoodanige kade had gewacht op het overleg met de technische direstie van den Noordooster-locaal spoorweg. Aanvankelijk had men het eindpunt van dien spoorweg aan de zuidzijde van de haven, bij de uit- 
waterings-sluis van Duurswold ontworpen, maar de Minister had beslist, dat het beter was, dien nieuwen spoorweg te doen aansluiten bij het station van den bestaanden Staats-spoorweg aan de Noordwestzijde. Aan die zijde zou dan ook de kade moeten worden gemaakt. Blijkt het verkeer grootere eischen te stellen, dan biedt de Zuidoostzijde van de haven gelegenheid tot uitbreiding. Het mocht den Minister, door deze uiteenzetting van zijne plannen gelukken, zelfs den Heer van Karnebeek te winnen voor de proefneming. Ook in de Eerste Kamer werd blijkens het voorloopig verslag de uitbreiding van de haven van Delfzijl als een nationaal belang door sommige leden voorgestaan en evenzeer door anderen het standpunt, door den Heer Van Karnebeek in de Tweede Kamer ingenomen, beplejt.

Bij de aanbieding zijner begrooting voor 1901 werd door den Minister Lely een veel grootere som voor Delfzijl aangevraagd, dan die, welke bij 'de behandeling der vorige begrooting als vereischte voor het door hem noodzakelijk geachte werk was gesteld. Was toen dat werk voorloopig geraamd op $\mathrm{f} 300.000$, nu, met de nitgewerkte plannen voor zich, vroeg de Minister ann de Kamer daarvoor een crediet van f 700.000. Het onderzoek der plannen door de hoofdambtenaren van den Waterstaat had den Minister de overtuiging geschonken van de noodzakelijkheid om de fundeering der kade tegen paalworm te beschermen en deed hem den eisch stellen, dat eene diepte van 11 M. - N. A. P. (=12.13 M. beneden gemiddelden vloed) in de toekomst mogelijk zoude moeten zijn. Daarom had dan ook de Minister geen vrijheid gevonden tot de anbesteding over te gaan, alvorens de machtiging voor die grootere uitgaaf van de Kamer te hebben verkregen ${ }^{1}$ ) De Heeren Roessingh, Schepel en Smeenge gaven in de Tweede Kamer, de Heer Alberda van Ekenstein in de Eerste Kamer blijk van hunue belangstelling en instemming en de Minister verkreeg de gevraagde machtiging zonder oppositie. Wel was door verschillende sprekers, zoowel in de openbare zitting, als, blijkens het voorloopig verslag, bij de behandeling in de afdeelingen, op bespoediging van het ontworpes werk aangedrongen en de

1) Zie openbare beraadslaging over Hoofdstuk IX op 18 December 1900 . 
Minister, eenerzijds verklarend de onvermijdelijkheid vian de verträging, vond anderzijds aanleiding zijne plannen voor de toekounst ten opzichte van Delfzijl nader te ontwikkelen. "Blijkt nu" zoo sprak de Minister, "dat hierdoor (n. l. door den bouw "der ontworpen kade) werkelijk handel komt, dan zal de verdere "verbetering der haven van Delfzijl een werk moeten worden "van enkele millioenen, een werk, dat dan eventueel door "eene staatscommissie zal kunnen worden voorbereid, "en later nog: "Trekt deze (de kade) dan scheepvaart -- en ik heb "eenige hoop, dat dit zoo zijn zal, want ik heb van een goede "firma vernomen, dat aij nu reeds schepen wil laten anbouwen "voor een geregelde vaart tusschen Delfzijl en Engeland "dan zal men, zooals ik straks zeide, tot den bouw eener "nieuwe kade moeten overgaan. Aan de Oostzijde zal men dan "eene haven moeten maken en deze in verband brengen met "den Noordooster-locaalspoorweg" Den 24 ${ }^{\text {n }}$ December 1901 werd het werk, door den Minister Lely voorbereid, door zijnen opvolger uitbesteed en aangenomen voor f 612.000 door de firma J. van Noordenne te Utrecht.

$\mathrm{Bij}$ de behandeling van de begrooting voor 1902 vond de heer Schepel aanleiding, on op spoedigen voortgang aan te dringen en eene vergelijking te maken tusschen de groote kosten voor kanaal- en rivierwerken in het centrum des lands en de post van $\mathbf{f 1 7 2 . 9 5 0}$ op deze begrooting tem behoeve van Delfzijl uitgetrokken.

En de Minister de Marez Oijens antwoordde daarop o. a., dat hij der haven van Delfzijl zeer geuegen is, dat het hem evenwel voorkomt, dat de voorstelling niet geheel juist is, alsof het hier geldt eene concutrentie tusscheu Bmden en Delizijl, maar dat de concurrentie met Emden niet behoort te worden opgevomen door Delfzijl, maar elders, nl. door Amsterdam en Rotterdam.

Volledigheidshalve woet $i k$ nog melding maken van de inlichtingen, door 's Ministers voorganger, den heer Lely, aan de Kamer verstrekt, naar anleiding van drie adressen betreffende de uitrieping der haven van Delfzijl en tot bespoedigivg van den aanleg van den Noordooster-locaalspoorweg. 1)

$\mathrm{Na}$ te hebben aangetoond, waarou eene verplatsing van een

1) Zitting $1899-1900$, No 184. 
belangrijk deel van het verkeer van Rotterdam of Amsterdam naar Emden via het Dortmund-Eemskanaal niet te verwachten is op soortgelijke gronden, als door mij in het eerste gedeelte van dit artikel ontwikkeld, deelt de Minister mede, dat hij, nadat op 1 Juli 1897 de haven in beheer en onderhoud aan het Rijk was gekomen, dadelijk een onderzoek had doen instellen naar de maatregelen, die zouden kunnen worden genomen om de haven beter aan hare bestemming te doen beantwoorden en het verkeer derzelve te vergemakkelijken. Gewezen wordt op de toeneming sedert 1884 van het aantal en vooral van den inhoud der in- en uitgeklaarde schepen en ook op de waarschijnlijkheid, dat Delfzijl eenige vermeerdering van verkeer zal verkrijgen ten gevolge van den nieuwen Duitschen waterweg, die het kolenvervoer van de Ruhr in gemeenschap brengt met de Eemshavens, en op den te wachten invloed van de aansluiting aan deu Noordooster-locaalspoorweg.

De werken, waarvan het door den Minister ingesteld onderzoek de wenschelijkheid en uitvoerbaarheid had aangetooud, zijn :

$1^{\circ}$. Verbreeding vau deu havenmond aan de Westzijde, ten einde de haven gemakkelijker te kunnen in- en uitvaren;

$2^{\circ}$. Opruiming van het lage deel van Zeehoofd $n^{0} 2$, ten einde de diepte van de Eems nader bij de haven te brengen;

$3^{\circ}$. Uitbreiding van de ligplaats voor zeeschepen door baggerwerk;

$4^{\circ}$. Aanleg van eene los- en laadkade voor zeeschepen;

50. Aanleg van eene los- en laadkade voor binnenvaartuigen, en

$6^{\circ}$. Aanleg van eenen dam, die de ten Oosten van den mond vau het uitwateringskanaal van Duurswold gelegen slikken vau de haven scheidt, waarvan bezuiniging van het onderhoudsbaggerwerk mag worden verwacht.

De werken onder $1^{\circ}, 2^{\circ}, 3^{\circ}$ en $6^{\circ}$ genoemd, kwamen reeds in 1899 tot uitvoering. De haven werd daarbij gebracht op eene diepte $\operatorname{van} 5.50$ M. - N. A. P., overeenkomend met 6.63 M. onder gemiddelden vloed. De haven van Emden, zoo beweert de Minister, kan in verband met de afmetingen van de grootste der beide schutsluizen, van uit de Eems slechts bereikt worden door schepen van $100 \mathrm{M}$. lengte, $6 \mathrm{M}$. diepgang en $14 \mathrm{M}$. breedte ${ }^{1}$ ).

1) Dit rapport is gedagteekend van 14 Mei 1900. Sedert dien tijd is, gelijk ik in het eerste deel van dit opstel in het Februari 
De Minister bespreekt dan den door hem voorgenomen kadebouw ter lengte van 225 bij de Waterpoort, die in December 1.1. werd uitbesteed en zegt, dat van af het Zuidelijk uiteinde dier kade tot an de Iamstersluis eene beschoeiing ter lengte van 250 M. voor binneuschepen zonde kunnen worden aangelegd en outwikkelt verder zijne plannen voor de toekomst, evenals ter gelegenheid van de behandeling zijner begrooting in de Tweede Kamer.

Nadere inlichtingen, bij missive van 13 Dec. $\left.1900^{1}\right)^{\prime}$ door den Minister verstrekt naar aanleiding van een adres van de werkliedenvereeniging "Exelsior" te Delfzijl, behandelen voornamelijk de klachten over onvoldoende diepte en onvoldoende ruimte in de haven, ten gevolge waarvan eenige schepen, alvorens te kunnen binnenkomen, op de reede moesten worden gelicht, en andere aan den grond waren gevaren. De Minister toont aan, dat het laatste een gevolg was van binnenvareu bij $e b$, en in é́n geval van een verkeerde manoeuvre, maar erkent ook tegelijk de noodzakelijkheid van grootere uitdieping dan tot $5.50-$ N. A. P.

Tot zoover wat betreft de bemoeiingen der regeering met deze haven.

Kan men met het door haar ingenomen standpunt van geleidelijk voortgaan, naar mate de behoefte blijkt, vrede hebben? Naar 't mij voorkomt, hoewel de voorzichtigheid in dezen, in 't belang van 's Rijks schatkist zeker te prijzen is, kan instemming met dat standpunt slechts voorwaardelijk zijn. Voorwaardelijk in zoover, dat niet gewacht worde met het iurichten vau de haven voor een grooter verkeer, totdat dit verkeer uit de cijfers zal zijn gebleken, maar dat men scherp lette op neiging tot uitbreiding, die na de totstandkoming van het werk, uu in uitvoering, zich naar ik hoop en verwacht zal vertoonen. Immers voor een groot verkeer zal ook na de uitvoering van dat werk de haven niet toegerust zijn. Daarvoor zal ook dan ontbreken, wat aan Emden met ruime hand is toebedeeld, een groote wateroppervlakte met overal voldoendeu diepgang, niet alleen

nummer van dit tijdschrift mededeelde, de buitenhaven van Enden voor schepen van veel grootere afmetingen en veel grooter diepgang ingericht, en heeft deze vergelijking dus hare beteekenis verloren.

1) Zitting $1900-1901, \mathrm{~N}^{\circ} 75$. 
langs eene kade, die ligplaats biedt voor niet meer dan twee groote schepen, groote kadelengte, electrische- of stoomkranen voor het laden en lossen en opslagplaatsen tot berging van de geloste goederen. De bestaande haven, van zeer onregelmatigen vorm, heeft een wateroppervlak van \pm 13 hectaren, waarvan echter bijna 5 hectaren van minder diepte dan 5 M. - N. A. P. en bij eb gedeeltelijk droograllend, zoodat eigenlijke havenruimte op geen grooter oppervlak dan ruim 8 hectaren te schatten is. De Emder buitenhaven $1500 \mathrm{M}$. lang en $120 \mathrm{M}$. breed, heeft de dubbele oppervlakte en overal diep water. En $\mathrm{nu}$ is de mogelijkheid niet uitgesloten, dat, bij al te strenge toepassing van het systeem der regeering, de betere inrichting der haven zal wachten op het grootere verkeer en het grootere verkeer op de betere inrichting. De vrienden van Delfzijl zullen dus wakker moeten blijven.

Aan het ontwerp van de heeren Van Hasselt en de Koning, reeds met een enkel woord door mij besproken, ligt hetzelfde denkbeeld ten grondslag als aan de plannen voor de toekomst van den Minister Lely, nl. uitbreiding van de bestaande haven aan de Zuidoostzijde. In het rapport aan de vereeniging, in wier opdracht zij bet ontwerp maakten, vindt men op pag. 17 en 18 de gronden aangegeven, waarom zij dit beter achten dan het maken van eene binuenhaven met groote zeesluis. Eene buitenhaven heeft natuurlijke voordeelen, die eene binuenhaven mist en zal aanzienlijk minder kosten. Voor de bijzonderheden van het ontwerp zij verwezen naar het rapport, waarbij eene schetsteekening is gevoegd. Ik moet mij bepalen tot eene omschrijving in grove trekken. De haven zal, met inbegrip der ontworpen handelsterreinen een oppervlak van \pm 18 hectaren verkrijgen; zij zal door eenen $800 \mathrm{M}$. langen dam aan de Noordoostzijde van de zee worden afgescheiden, aan de Oostzijde aansluitend aan den hestaanden dijk. Tusschen de bestaande haven en het aldus afgesloten gedeelte van den Dollard wordt een tijdelijke afsluitdam gelegd, ter lengte van $600 \mathrm{M}$. Beide afsluitdammen worden aangelegd tot boven stormvloedhoogte, zoodat een polder verkregen wordt, waarin vrij kan worden gewerkt, zonder dat-eenige wijuiging der be- 
staande haven of stoornis in het verkeer aldaar plaats vindţ. Daardoor wordt het voordeel verkregen, dat de muren in drogen grond, net behulp van bemaling kunnen worden gefundeerd. Deze muren zullen worden gefundeerd op beton. Evenwij,dig met den bovengenoemden afsluitdam, en daarvan gescheiden door een $75 \mathrm{M}$. breed bassin, wordt een tweede kade gemaakt. Zoo ontstaan twee havenbassins, het eene tusschen de beide dammen $550 \mathrm{M}$. lang en $75 \mathrm{M}$. breed, het andere $325 \mathrm{M}$. lang en $300 \mathrm{M}$. breed, aan de open zijde naar de bestaande haven, $75 \mathrm{M}$. aan de landzijde. Op beide kaden, die gebracht worden boven stormvloedhoogte, en die dus niet, zooals die langs de Emder buitenhaven, nu en dau aan overstrooming zullen blootstaan, ell die eene breedte van $50 \mathrm{M}$. zullen verkrijgen, komen dan de handelsinrichtingen, bergplaatsen, $\left(14000 \mathrm{M}^{2}\right)$ kranen, spoorwegaansluitingen. De kosten van het geheele werk worden geraamd op $\mathrm{f} 5.180 .000$.

In de op 8, 9 en 10 Juli 1901 te Haarlem gehouden Algemeene vergadering van de Nederlandsche Maatschappij ter bevordering van nijverheid werd op verzoek van Groningens afgevaardigde, den heer U. G. Schilthuis Jzn. de zaak van de haven te Delfzijl besproken en door hem voorgesteld de regeering te verzoeken, het daarheen te leiden, dat de haven te Delfzijl voor de scheepvaart voldoende worde verbeterd. De voorsteller wees op het plan van Hasselt en de Koning en noemde de verbetering een nationaal belang. De Voorzitter meende, dat, wilde men met de haven te Emden kunnen mededingen, het genoemde plan op te kleine schaal was ontworpen, herinnerde aan het plan van den Minister Lely, wees er op, dat de ontwerpers het gevaar van den paalworm uit het oog verloren hadden en keurde de door hen ontworpen paalfundeering op dien groud af, terwijl hij oordeelde, dat Groningen zich voor de haven van Emden niet beducht behoefde te maken, daar de geul door het Oost-Friesche gaatje niet te houden zoude zijn.

Den mogelijken invloed van de verbreeding en verdieping. van het Oostfriesche gaatje op de diepte ter reede van Delfzijl besprak ik in het eerste deel van dit opstel. Zouder den Duitschers het welslagen van hun werk te misgunnen, hoop ik, dat onze regeering proefondervindelijk zal kunnen doen aan- 
toonen, dat vrees voor vermindering van diepte langs onze kust niet behoeft gekoesterd te worden.

En moge het al waar zijn, dat het plan van Hasselt en de Koning op te bescheiden schal is ontworpen, de uitvoering ervan zal er dan toch toe leiden, dat het wateroppervlak in de haven te Delfzijl ongeveer verdubbeld en ongeveer gelijk aan dat van de buitenhaven te Eraden zal worden. De schepen van 170 a 180 M., door den Voorzitter genoemd als de grootsten, kunnen in het bassin ter lengte van $550 \mathrm{M}$. plaats vinden. De inrichtingen, voor laden en lossen noodig, zullen deze er antreffen. En blijkt later de ontworpen ruimte te gering, dan zal de levensvatbaarheid van de haven voldoende bewezen zijn, om verder strekkende plannen te rechtvaardigen. Aan het aan den paalworm ontleende bezwaar van den Voorzitter, ziju de ontwerpers later tegemoet gekomen, door de parlfundeering door eene van beton te vervangen.

De technische waarde van dit ontwerp te beoordeelen, zij aan meer bevoegden overgelaten. Het komt mij voor, op gelukkige wijze het probleem te hebben opgelost. Indien het plan voor den prijs door de ontwerpers geraand, kan worden uitgevoerd, dan zal Nederland in een nieuwe groote haven, die aau een oude haudelsstad en aan een uitgestrekte streek met eene nijvere, euergieke bevolking gelegenheid tot krachtiger ontwikkeling zal schenken, een kostbaar bezit met geringe opoffering kunnen verwerven.

De vraag of Delfzijl zal concurreeren met Emden en aan deze Duitsche haven afbreuk zal doen of niet, alsook of Rotterdam en Amsterdam dan wel Delfzijl de concurrentie inet Emden zullen moeten opnemeu, schijnt mij van weinig gewicht. De bloei van Emden, ten gevolge van de ontwikkeling van zijn achterland; kan Delfzijl slechts tot voordeel zijn en in zoover hebben beide plaatsen één geneenschappelijk belang. Botterdam en Austerdam zullen de ontwikkeling van een nieuwe haven in het Noorden wel niet met jaloersche oogen aanzien. Beide hebben hun eigen verkeer en zullen dat behouden, trots Emden en Delfzijl.

Groningen.

G. MesdaG JaZ. 